\title{
Thin Films Produced on 5052 Aluminum Alloy by Plasma Electrolytic Oxydation with Red Mud-containing Electrolytes
}

\author{
Lívia Sottovia ${ }^{a *}$, Maria Lúcia Pereira Antunes ${ }^{a}$, César Augusto Antonio ${ }^{a}$, \\ Elidiane Cipriano Rangel ${ }^{a}$, Nilson Cristino da Cruz ${ }^{a}$ \\ aUniversidade Estadual Paulista - UNESP, Av. Três de Março, 511, \\ CEP 18087-180, Sorocaba, SP, Brazil
}

Received: April 3, 2014; Revised: December 18, 2014

\begin{abstract}
In this paper, we propose the production of ceramic protective thin films by plasma electrolytic oxidation using red mud-containing electrolytes. The treatments were performed through the application of pulsed voltage $(600 \mathrm{~V}, 200 \mathrm{~Hz})$ during 300 seconds to aluminum samples immersed in electrolytic solutions with $5 \mathrm{~g}$ of red mud per liter of distilled water. The coatings were characterized by X-ray diffraction (XRD), scanning electron microscopy (SEM), X-ray energy dispersive spectroscopy (EDS) and contact angle and surface energy measurements. The final current density during the experiments was $0.05 \mathrm{~A} / \mathrm{cm}^{2}$ and films as thick as $9.0 \mu \mathrm{m}$ have been obtained. XRD patterns have clearly shown the incorporation of species from the red mud on the coating.
\end{abstract}

Keywords: plasma electrolytic oxidation, ceramic coatings, red mud

\section{Introduction}

Aluminum is widely used in aerospace, automotive, marine and domestic industries, due to its lightness, durability, thermal and electrical conductivity, strength, ductility and weldability ${ }^{1,2}$. It is a very chemically active material, despite the passivating alumina film that is easily formed on its surface when in contact with oxygen ${ }^{3}$. However, some pollutants can lead to corrosion and, consequently, the reduction of mechanical strength ${ }^{1}$. In this context, ceramic coatings are potentially a good solution to increase the resistance to corrosion and wear of metal surfaces ${ }^{4}$, increasing their useful lives.

The plasma electrolytic oxidation (PEO) is a technique that combines atmospheric arc plasmas in an aqueous solution with the known processes of metal oxidation by electrolysis ${ }^{5}$. Such technique allows the production of oxide films on lightweight metals, such as aluminum, titanium and magnesium. Since the process involves the oxidation of the substrate and the incorporation of species in the electrolytic solution, the properties of the coatings depend on the combination of the substrate and the electrolyte solution. In particular, for the production of aluminum oxide coatings, rapid dissolution of aluminum could be achieved with $\mathrm{NaCl}$, $\mathrm{NaOH}, \mathrm{NaClO}_{3}, \mathrm{HCl}$, and $\mathrm{NaNO}_{3}$ solutions ${ }^{6}$.

The red mud (RM) is a residue from the clarifying Bayer process. It is a highly alkaline insoluble solid containing significant amount of elements such as iron, silicon, titanium and aluminum ${ }^{7-9}$. Such characteristics suggest the red mud to be considered as a promising material to be used in electrolyte solutions for coating of aluminum by PEO since the incorporation of such valuable elements in the coating may contribute to the improvement of wear and corrosion resistances of the substrates. The red mud has been studied

*e-mail: liviasottovia@gmail.com for the construction industry, adsorbent metals and organic materials and $\mathrm{CO}_{2}$ capture ${ }^{7}$. In recent years it has been studied as ceramic films for protecting metals ${ }^{10-13}$.

In this paper, we have studied the production and characterization of ceramic films produced by plasma electrolytic oxidation of red mud-based electrolytes as a possible value added destination to this residue.

\section{Material and Methods}

\subsection{Red mud preparation and characterization}

The red mud used in this study was collected in wet form from an industrial bauxite processing plant, located in Alumínio-SP, Brazil. Red mud samples were dried at $50^{\circ} \mathrm{C}$ in a muffle for 24 hours, and then they were macerated and stored. The morphology of red mud samples were observed by Scanning Electron Microscopy (SEM) using a JEOL JSM-6010LA microscope fitted with an X-ray energy dispersive spectrometer unit (EDS). Mineral composition was determined by X-ray Diffraction (XRD), using a Panalytical X'Pert powder diffractometer operating at $45 \mathrm{kV}, 40 \mathrm{~mA}$ with $\mathrm{CuK} \alpha$ radiation.

\subsection{Electrolytic solution and substrate preparation}

The electrolytic solution was prepared with $5 \mathrm{~g} / \mathrm{L}$ of red mud, potassium hydroxide and distilled water. The solution had a $\mathrm{pH}$ of 11.5052 aluminum alloy, containing $0.25 \%$ wt Si, $0.40 \%$ wt Fe, $0.10 \%$ wt $\mathrm{Cu}, 0.10 \%$ wt $\mathrm{Mn}$, $2.2-2.8 \%$ wt $\mathrm{Mg}$, between 0.15 and $0.35 \%$ wt $\mathrm{Cr}, 0.10 \%$ wt $\mathrm{Zn}, 0.15 \%$ wt of other elements ${ }^{14}$ was used as substrate. The dimension of substrates was standardized at $25 \times 25$ $\times 1.3 \mathrm{~mm}^{3}$. The samples were sandpapered, polished and 
cleaned with ultrasonic baths in distilled water, acetone and isopropyl alcohol.

\subsection{Deposition and characterization of ceramic films of red mud}

The samples immersed in the electrolytic solution were connected to the positive terminal of a pulsed power supply (MAO Power Supply) operating at 600 V, $200 \mathrm{~Hz}, 60 \%$ of duty cycle, during 300 seconds. After the treatments, the samples were dried with a hot air gun and analyzed by contact angle and surface energy (Ramé-Hart, model number 100-000), SEM, EDS, XRD and the coating thicknesses were measured at least ten times in four different positions using the eddy current method (Politerm microprocessor CM-8825FN). Distilled water was used as test liquid in contact angle (CA) measurements. Three drops were placed on different positions in each sample and at least ten measurements of each drop were performed immediately after the treatments and once in a week during the first month after the treatment, every fifteen days during the second month and, from then on, every thirty days. The procedure was employed to evaluate the surface energy. However, in that case, the probe liquid was diiodomethane.

\section{Results and Discussion}

\subsection{Red mud characterization}

As one can observe in Figure 1, which shows a SEM micrograph of the dried RM, the powder is constituted by particles of different sizes and shapes, some of them are smaller than $5 \mu \mathrm{m}$ in diameter and without any regular pattern.

EDS spectra were taken in six randomly chosen points indicated in Figure 2 and the elements detected in each point are shown in Table 1.

Iron and aluminum oxides are more frequent and with higher proportions, although silicon is present in all analyzed points. The smaller and more rounded particles are recurrent when there are higher proportions of iron, and the larger and more irregular particles contain higher percentage of aluminum. These results are in good agreement with the literature about red $\mathrm{mud}^{7}$.
The mineralogy of the red mud was analyzed by XRD and it complies with the literature ${ }^{7,15}$. In the XRD patterns of red mud given in Figure 3, it can be observed peaks corresponding to sodalite $\left(\mathrm{NaAlSi}_{4} \mathrm{O}_{12} \mathrm{Cl}\right)$, gibbsite $\left(\mathrm{Al}(\mathrm{OH})_{3}\right)$, goethite $(\mathrm{FeO}(\mathrm{OH}))$, hematite $\left(\mathrm{Fe}_{2} \mathrm{O}_{3}\right)$, kaolinite $\left(\mathrm{Al}_{6} \mathrm{Si}_{2} \mathrm{O}_{2}-(\mathrm{OH})_{4}\right)$, calcite $\left(\mathrm{CaCO}_{3}\right)$, quartz $\left(\mathrm{SiO}_{2}\right)$ and perovskite $\left(\mathrm{CaTiO}_{3}\right)$. Hematite, perovskite, goethite and gibbsite are the main components in red mud.

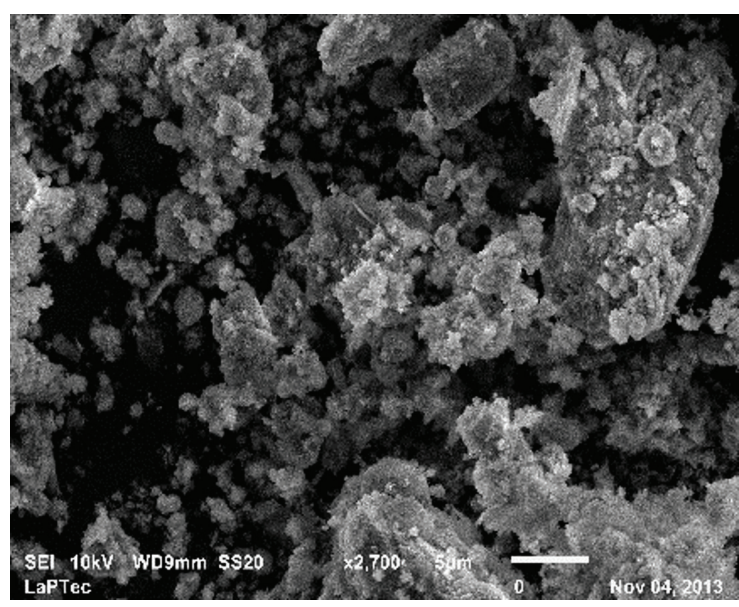

Figure 1. SEM micrograph of dried red mud.

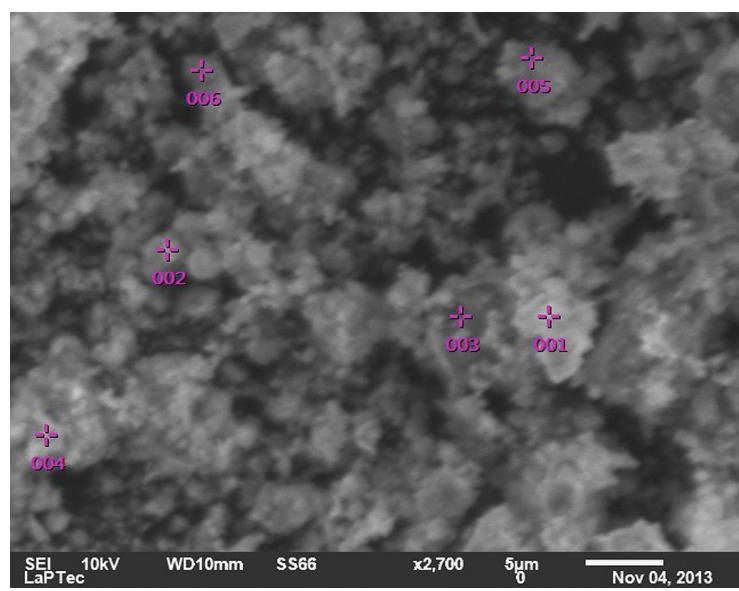

Figure 2. SEM micrograph indicating the points analyzed by EDS.

Table 1. Dried red mud atomic composition as determined by EDS on the points indicated in Figure 2.

\begin{tabular}{lcccrrr}
\hline \multirow{2}{*}{ Elements } & \multicolumn{7}{c}{ Atomic composition (\%) } \\
\cline { 2 - 7 } & Point 1 & Point 2 & Point 3 & Point 4 & Point 5 & Point 6 \\
\hline Carbon & 3.19 & 6.73 & 3.01 & 7.51 & 23.55 & 3.36 \\
Oxygen & 36.50 & 44.79 & 47.19 & 37.69 & 34.92 & 40.29 \\
Sodium & 1.87 & 7.68 & 2.04 & 4.20 & 1.23 & 3.35 \\
Aluminum & 14.67 & 16.23 & 43.36 & 11.18 & 20.82 & 11.15 \\
Silicon & 7.97 & 13.39 & 3.85 & 7.71 & 1.03 & 3.52 \\
Phosphorus & - & - & 0.55 & 2.22 & - & - \\
Sulfur & - & 0.54 & - & 0.57 & - & - \\
Calcium & 2.51 & 0.87 & - & 7.20 & 1.01 & 0.67 \\
Titanium & 3.30 & - & - & 20.71 & 17.78 & 1.48 \\
Iron & 30.00 & 9.77 & - & & 36.30 \\
\hline
\end{tabular}




\subsection{Characterization of red mud coatings}

Figure 4 shows the average current density, $\rho_{I}$, as a function of treatment time. Some authors ${ }^{16}$ consider the current density as one of the most important parameter in a PEO process because, according to the first Faraday law, the coating growth under certain conditions is directly proportional to the electric charge across the solution ${ }^{17}$. Therefore, the decrease in $\rho_{I}$ observed in Figure 4 suggests the decrease of the deposited mass during the treatment. The average film thickness attained after $300 \mathrm{~s}$ of treatment was $8.9( \pm 3.3) \mu \mathrm{m}$.

The contact angle and surface energy results are presented in Figures 5 and 6, respectively.
The contact angle and the total surface energy, $E_{S}$, of the as-received aluminum sample were $64.9^{\circ}$ and $50.3 \mathrm{Dyn} /$ $\mathrm{cm}$, respectively. The contact angle, that was too low to be measured at the first day after the treatment, increased continuously reaching $82^{\circ}$ after aging for eight weeks. The total surface energy has increased to $72.0 \mathrm{Dyn} / \mathrm{cm}$ after the first week and then decreased to $42.0 \mathrm{Dyn} / \mathrm{cm}$, reflecting the decreasing of the polar component of $E_{S}$.

Figure 7 presents typical SEM micrographs of the coatings.

The images show a porous surface with plateaus and granular parts. As it can be observed, the porous diameters are typically smaller than $5 \mu \mathrm{m}$.

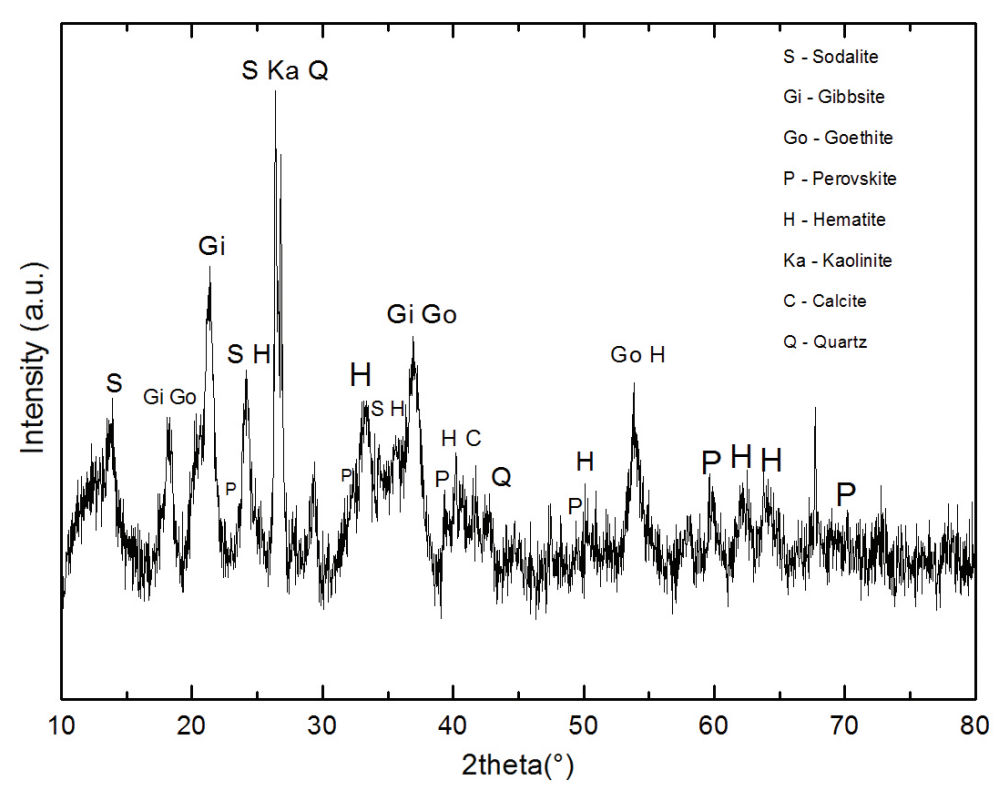

Figure 3. XRD patterns of dried red mud.

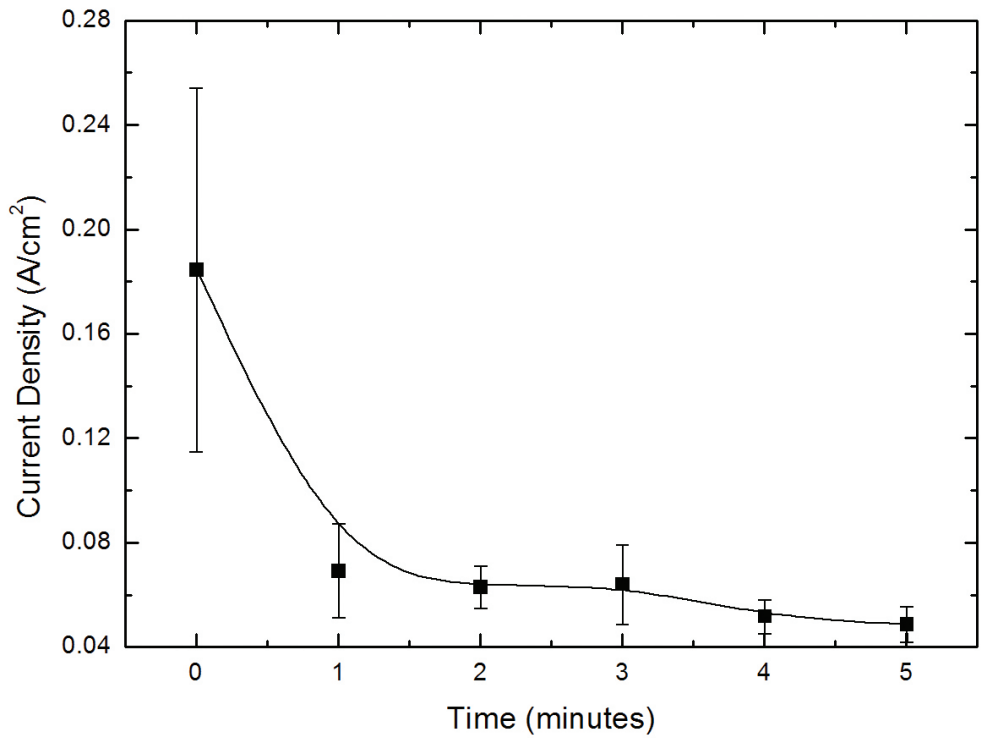

Figure 4. Current density as a function of treatment time. 


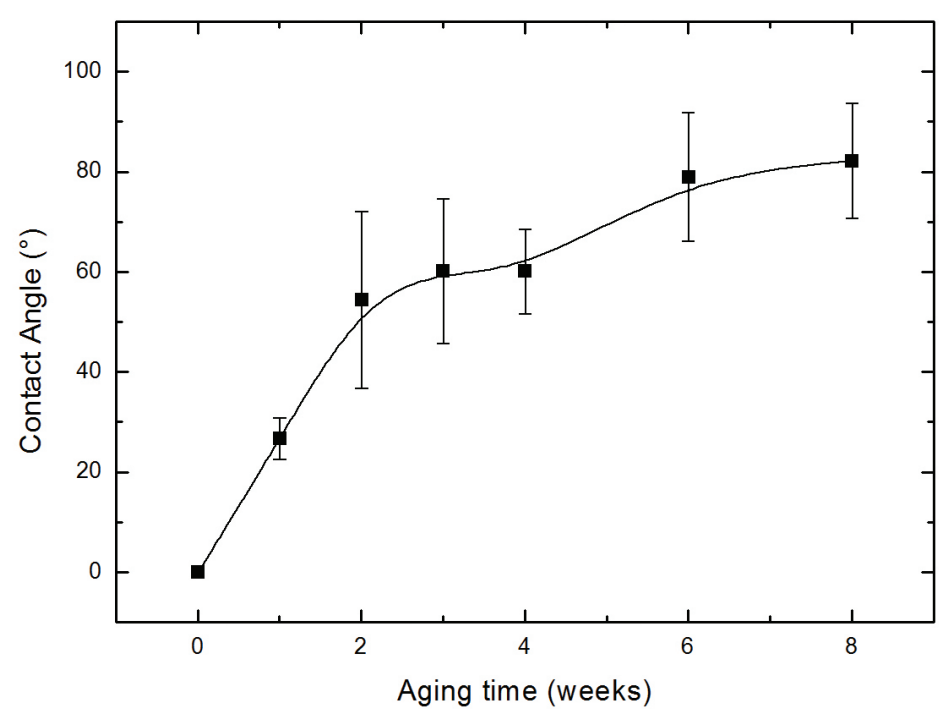

Figure 5. Contact angle of the coatings as a function of aging time.

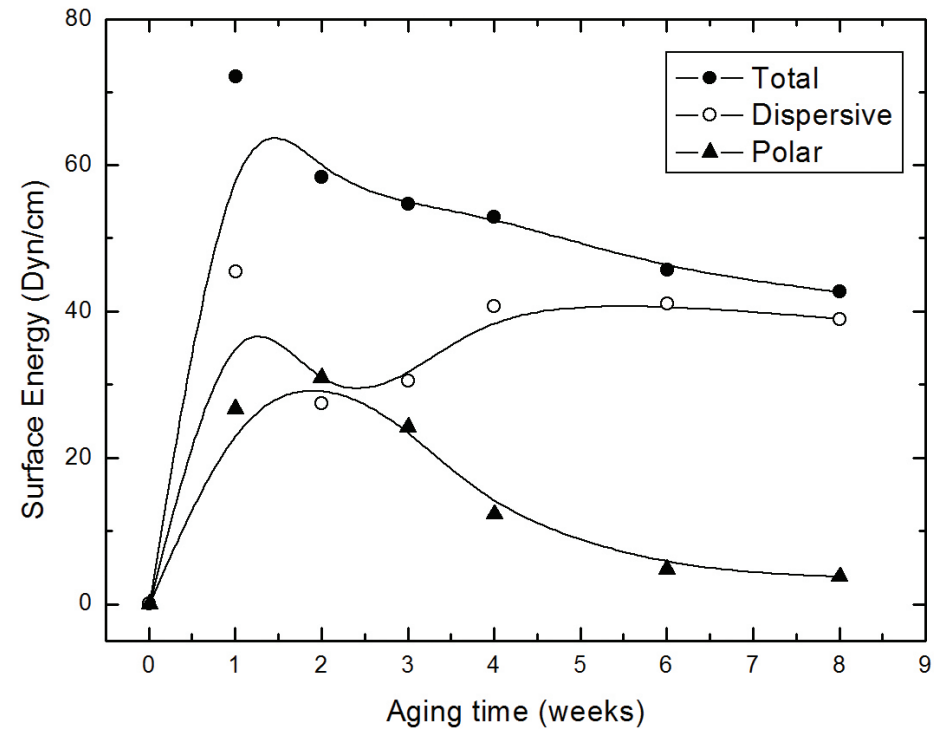

Figure 6. Surface energy and its components as a function of aging time.

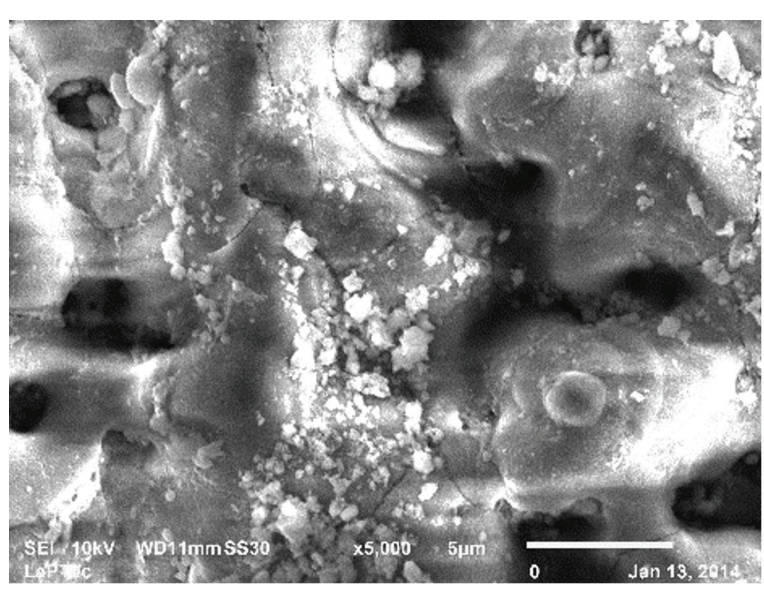

(a)

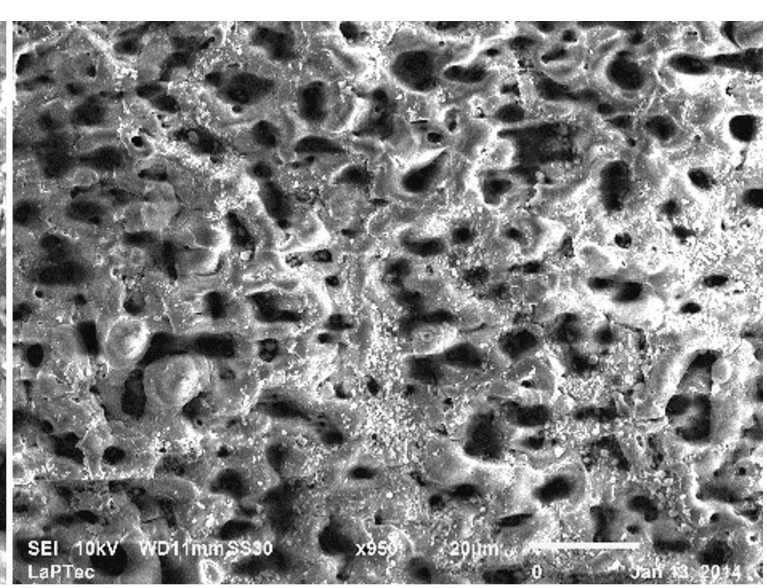

(b)

Figure 7. SEM micrographs with two magnifications of red mud coating. 
Table 2. Atomic composition, as determined by EDS, in four points randomly chosen on coatings produced by PEO from red mud electrolytes.

\begin{tabular}{lcccr}
\hline \multirow{2}{*}{ Elements } & \multicolumn{5}{c}{ Atomic composition (\%) } \\
\cline { 2 - 5 } & Point 1 & Point 2 & Point 3 & Point 4 \\
\hline Carbon & - & - & - & 4.34 \\
Oxygen & 3.43 & 8.26 & 39.38 & 27.67 \\
Sodium & 2.17 & 0.28 & 0.21 & 1.02 \\
Aluminum & 23.44 & 39.22 & 50.67 & 50.42 \\
Silicon & 3.82 & 0.59 & 0.67 & 4.15 \\
Mg & 0.49 & 0.68 & 1.50 & 0.81 \\
Iron & 32.65 & 50.98 & 7.57 & 11.59 \\
\hline
\end{tabular}

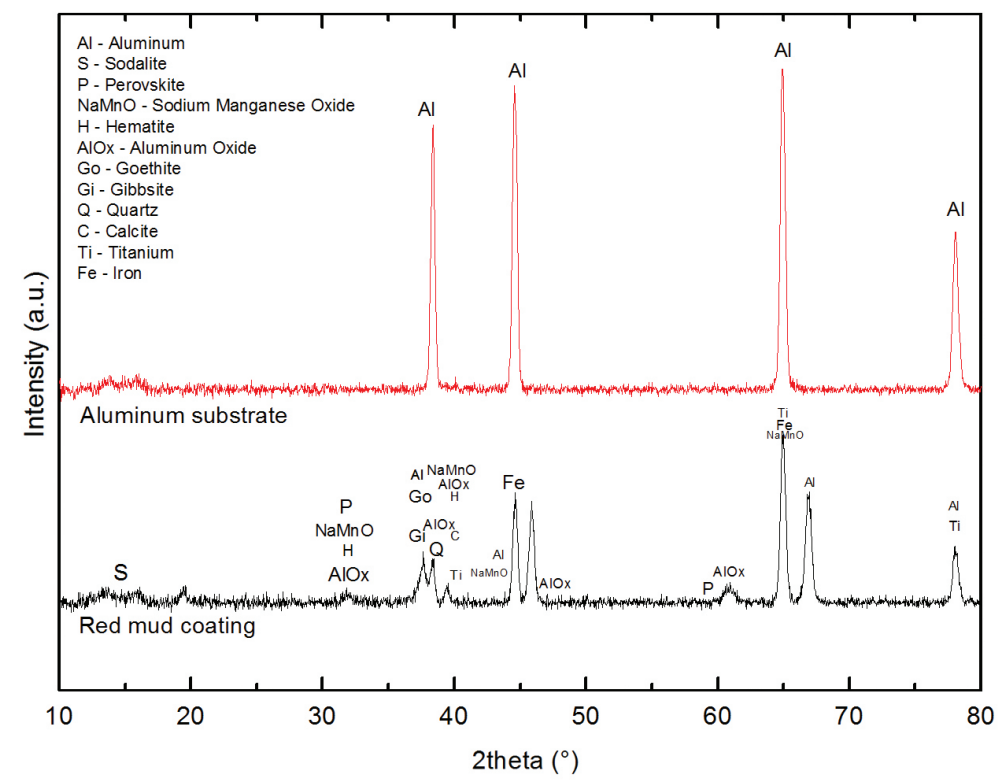

Figure 8. XDR patterns of aluminum substrates and red mud coating.

In Figure $7 b$, one can note the presence of smoother or nodular regions, which are indicative of particle coalescence. It is interesting to point out that although such structures are normally observed after exposing the material to very high temperatures ${ }^{18}$, above its melting point, they have been formed with treatments in electrolytes whose temperatures have not exceeded $90{ }^{\circ} \mathrm{C}$.

Table 2 presents the atomic composition as determined by EDS spectra collected in four points chosen randomly over the entire sample surface. It is worthy to note that the coalesced regions are constituted mainly by aluminum, suggesting the alloying of the substrate with electrolyte species.

In addition, some elements, such as sulfur, phosphorous, calcium and titanium, present in the red mud have not being incorporated to the coating, indicating that physicochemical effects, rather than purely amalgamation, are responsible for the growth and the properties of the coatings.

The X-ray patterns of aluminum substrate and substrate after PEO processing are given in Figure 8. Although only aluminum is observed on the diffractogram of the bare substrate, it can be observed a plentitude of species such as sodalite, hematite, calcite, quartz, gibbsite, goethite and perovskite on the X-ray pattern of the coated aluminum. Furthermore, other mineralogical components, such as titanium, iron, aluminum oxide and sodium manganese oxide, were also identified. Since some of these elements have not been detected by EDS, this result indicates that they are present in deeper regions not assessed by EDS.

\section{Conclusion}

It has been demonstrated the possibility to produce complex ceramic coatings by plasma electrolytic oxidation of aluminum substrates using red mud based-electrolytes. Coatings as thick as $9 \mu \mathrm{m}$ have been grown after $300 \mathrm{~s}$ of treatment. The aging in air during 8 weeks caused the water contact angle, initially null, to increase up to $82^{\circ}$. Such decrease in surface hydrophilicity was a consequence of the decrease of the density of polar groups on the surface, as evaluated with surface energy measurements. It has been detected the formation of species such as sodalite, hematite, calcite, quartz, goethite, gibbsite and perovskite, which are supposed to confer enhanced wear and corrosion resistances to the surfaces.

\section{Acknowledgements}

The authors would like to thank CAPES and FAPESP, through grant 2011/23733-8, for financial support. 


\section{References}

1. Abreu F. Avaliação da resistência à corrosão da liga de alumínio 6101 após diferentes tratamentos térmicos de precipitação. Corrosão e Protecção de Materiais. 2012; 31(3-4):65-70.

2. Associação Brasileira do Alumínio - ABAL. Alumínio. São Paulo. Available from: <http://www.abal.org.br/>. Access in: 19/02/2013.

3. Oliveira CR. Alteração das propriedades superficiais do alumínio via eletrólise a plasma. [Dissertation]. Sorocaba: Universidade Estadual Paulista; 2010.

4. Gu WC, Lv G-H, Chen H, Chen G-L, Feng W-R and Yang $\mathrm{S}-\mathrm{Z}$. Characterisation of ceramic coatings produced by plasma electrolytic oxidation of aluminium alloy. Materials Science and Engineering. 2007; 447(1-2):158-162. http://dx.doi. org/10.1016/j.msea.2006.09.004.

5. Yerokhin AL, Snizhko LO, Gurevina NL, Leyland A, Pilkington A and Matthews A. Spatial characteristics of discharge phenomena in plasma electrolytic oxidation of aluminium alloy. Surface and Coatings Technology. 2004; 177-178:779-783. http://dx.doi.org/10.1016/j.surfcoat.2003.06.020.

6. Yerokhin AL, Nie X, Leyland A, Matthews A and Dowey SJ. Plasma electrolysis for surface engineering. Surface and Coatings Technology. 1999; 122(2-3):73-93. http://dx.doi. org/10.1016/S0257-8972(99)00441-7.

7. Antunes MLP, Couperthwaite SJ, da Conceição FT, Costa de Jesus CP, Kiyohara PK, Coelho ACV, et al. Red mud from brazil: thermal behavior and physical properties. Industrial \& Engineering Chemistry Research. 2012; 51(2):775-779. http:// dx.doi.org/10.1021/ie201700k.

8. Zhang N, Sun H, Liu X and Zhang J. Early-age characteristics of red mud-coal gangue cementitious material. Journal of Hazardous Materials. 2009; 167(1-3):927-932. http://dx.doi. org/10.1016/j.jhazmat.2009.01.086. PMid:19237241

9. Wang S, Ang HM and Tadé MO. Novel applications of red mud as coagulant, adsorbent and catalyst for environmentally benign processes. Chemosphere. 2008; 72(11):1621-1635. http://dx.doi.org/10.1016/j.chemosphere.2008.05.013. PMid: 18558418

10. Jayasankar K, Ray PK, Chaubey AK, Padhi A, Satapathy BK and Mukherjee PS. Production of pig iron from red mud waste fines using thermal plasma technology. International Journal of Minerals, Metals and Materials. 2012; 19(8):679-684. http:// dx.doi.org/10.1007/s12613-012-0613-3.

11. Sutar H. Morphology and solid particle erosion wear behavior of red mud composite coatings. Natural Science. 2012; 4(11):832-838. http://dx.doi.org/10.4236/ns.2012.411111.

12. Rath SS, Pany A, Jayasankar K, Mitra AK, Kumar CS, Mukherjee PS, et al. Statistical Modeling Studies of Iron Recovery from Red Mud Using Thermal Plasma. Plasma Science And Technology. 2013; 15(5):459-464. http://dx.doi. org/10.1088/1009-0630/15/5/13.

13. Satapathy A. Characterization of plasma sprayed pure red mud coatings: an analysis. American Chemical Science Journal. 2013; 3(2):151-163. http://dx.doi.org/10.9734/ $\mathrm{ACSJ} / 2013 / 3218$.

14. Milan MT. Metais: uma visão objetiva. São Carlos: Suprema; 2004.

15. Rivas Mercury JM, Cabral AA, Paiva AEM, Angélica RS, Neves RF and Scheller T. Thermal behavior and evolution of the mineral phases of Brazilian red mud. Journal of Thermal Analysis and Calorimetry. 2011; 104(2):635-643. http://dx.doi. org/10.1007/s10973-010-1039-7.

16. Guan YJ, Xia Y and Li G. Growth mechanism and corrosion behavior of ceramic coatings on aluminum produced by autocontrol AC pulse PEO. Surface and Coatings Technology. 2008; 202(19):4602-4612. http://dx.doi.org/10.1016/j. surfcoat.2008.03.031.

17. Halliday D, Resnick R and Walker J. Fundamentos de Física 3. 6rd ed. Rio de Janeiro: LTC; 1996.

18. Santos PS, Santos HS and Toledo SP. Standard transition aluminas: electron microscopy studies. Materials Research. 2000; 3(4):104-114. http://dx.doi.org/10.1590/S151614392000000400003 . 